\title{
EFFECT OF ALKALINE TREATMENT ON PROPERTIES OF RATTAN WASTE AND FABRICATED BINDERLESS PARTICLEBOARD
}

\author{
Zuraida AhMAD*, Maisarah Tajuddin, Nurul Farhana Fatin SAlim AND \\ ZAHURIN HALIM \\ ${ }^{I}$ Department of Manufacturing and Materials Engineering, Faculty of Engineering, \\ International Islamic University Malaysia, \\ Jalan Gombak, 53100 Kuala Lumpur, Malaysia. \\ "Corresponding author: zuraidaa@iium.edu.my \\ (Received: 18 $8^{\text {th }}$ Oct 2017; Accepted: $7^{\text {th }}$ Dec 2017; Published on-line: $1^{\text {st }}$ June 2018)
}

https://doi.org/10.31436/iiumej.v19i1.879

\begin{abstract}
Binderless particleboard (BPB) has become an alternative to avoiding the usage of synthetic resin, possessing excellent properties but having low dimensional stability characteristics. Hence, this study aims to investigate the effects of alkaline treatment on properties of rattan furniture waste (RFW) and fabricated BPB. The RFW was fully immersed in a $1 \%$ sodium hydroxide $(\mathrm{NaOH})$ solution for 10 minutes and dried in an oven at $35^{\circ} \mathrm{C}$ for two days. Then, the treated RFW was used to fabricate the BPB via a hot-pressing process at pressing parameters of $180^{\circ} \mathrm{C}$ and 5 minutes. The colour of the RFW changed to dark yellowish and chemical analysis showed some reduction in hemicellulose, lignin and ash content after the alkaline treatment, which have been confirmed through peak decline in Fourier Transform Infrared Spectroscopy (FTIR). Only cellulose content increased after treatment due to a disruption of hydrogen bonding on the fibre surface. The treated BPB panels had improved mechanical and dimensional stability compared to untreated BPB panels, and achieved the minimum requirement of board standards. Removal of the fibres' impurities, led to tremendous physical consolidation among fibres. The nature of the panels changed from hydrophilic to hydrophobic as water molecules were released from the fibres during the treatment process. These results were supported by Scanning Electron Microscopy (SEM) analysis that displayed cleaner RFW fibres and rougher surfaces on the treated BPB panels.
\end{abstract}

ABSTRAK: Papan partikel tanpa pelekat (papan BPB) menjadi salah satu alternatif bagi menggelak penggunaan pelekat sintetik, ianya mempunyai sifat-sifat terbaik walaupun keseimbangan dimensi papan masih berada pada tahap rendah. Oleh itu, tujuan kajian ini dijalankan adalah bagi menyelidik kesan rawatan alkali ke atas sifat sisa perabot rotan dan papan BPB yang dihasilkan. Sisa perabot rotan direndam penuh ke dalam cecair alkali Natrium Hidroksida $(\mathrm{NaOH})$ berkepekatan $1 \%$, selama 10 minit dan sesudah itu dikeringkan di dalam ketuhar pada suhu $35^{\circ} \mathrm{C}$ selama dua hari. Kemudian, sisa perabot rotan yang telah dirawat ini digunakan bagi menghasilkan papan BPB melalui kaedah tekanan haba pada suhu tekanan $180^{\circ} \mathrm{C}$ selama 5 minit. Warna sisa perabot rotan telah berubah kepada kuning gelap, dan hasil analisa kimia menunjukkan pengurangan pada hemi-selulosa, lignin dan komposisi abu dalam serat rotan selepas rawatan alkali dan terbukti melalui pengurangan nilai puncak pada analisa Fourier Transform Infrared Spectroscopy (FTIR). Hanya kandungan selulosa meningkat selepas rawatan alkali, disebabkan gangguan pada ikatan hidrogen pada permukaan serat. Papan BPB yang terhasil menggunakan serat dirawat telah menunjukkan peningkatan pada sifat mekanikal 
dan keseimbangan dimensi papan, serta mencapai piawaian minima papan, berbanding dengan papan BPB yang terhasil menggunakan serat tidak dirawat. Hal ini disebabkan pembuangan kotoran serat menghasilkan penyatuan fizikal yang sangat baik antara serat. Sifat semulajadi pada papan BPB juga telah bertukar dari hidrofilik kepada hidrofobik, kerana molekul-molekul air dilepaskan dari serat semasa rawatan alkali. Keputusan ini disokong melalui analisa Mikroskop Pengimbas Elektron (SEM) yang menunjukkan permukaan serat rotan RFW lebih jelas dan permukaan papan BPB yang lebih kasar.

KEYWORDS: waste; treated; strength; dimensional stability; morphology

\section{INTRODUCTION}

Particleboard is in high demand in many sectors due to cheaper, denser, and more uniform properties compared to conventional wood or plywood [1]. However, the use of synthetic resin inside the particleboard had raised concerns among manufacturers and users, as it is harmful to human health as well as the environment [2]. Binderless particleboard (BPB) is pressed via heat treatment to trigger a self-bonding mechanism inside the fibres, by activating the chemical components of the fibres [2-4]. BPB comes as an alternative to current particleboards as it can be produced without using any synthetic resin, which is safer for human health and more environmental friendly. Much innovative research on BPB has been conducted to transform waste into wealth, by utilising waste from natural fibres such as kenaf, bagasse, coconut husk, oil palm and many others [3-8].

There is a relatively high level of waste produced during the manufacture of rattan furniture $[9,10]$. Rattan furniture waste (RFW) has previously been disposed of by on-site incineration through open burning and illegal dumping that contribute to environmental issues, affect local and regional air quality, and eventually lead to global climate change [8$10]$. There is an urgency to promote RFW by converting this waste into BPB, as RFW has good chemical constituents that are expected to produce good quality BPB.

The main issue in BPB is the low dimensional stability characteristic, as natural fibres easily absorb moisture from surroundings $[2,4]$. The BPB has a high tendency to change its shape, bend, and warp after a certain period of time. At the same time, the bare surface of the BPB, having no added resin, made the BPB fragile and easily degradable although having high strength properties. Thus, alkaline treatment applied on the fibres might help to improve the properties of the fabricated BPB $[8,11]$. It is hypothesized that the treatment process creates a rough surface on the fibres that enhances the BPB properties. Alkaline treatment weakens and softens lignin bonds between the fibres, thereby producing less damaged and more flexible fibres [8,11-13]. As far as we can conclude from the literature, no research has been conducted on the alkaline treatment of RFW. It is worth studying and analysing the impact of applied alkaline treatment on the RFW and properties of the fabricated BPB, which are believed to have significant effect to the rattan furniture industry in Malaysia.

Therefore, the objective of this study is to investigate the effects of alkaline treatment on RFW including mechanical and dimensional stability properties of fabricated BPB. After undergoing alkaline treatment, the characterisations were conducted on RFW according to their physical, chemical and morphological properties. After that, the fabricated BPB was analysed based on Japanese Industrial Standard (JIS) A5908 [14], via bending, dimensional stability, and morphology tests. 


\section{MATERIALS AND METHODS}

The main material used for this project is rattan furniture waste (RFW) collected from a factory that manufactures rattan furniture as their main product, located in Perak, Malaysia. The rattan collected from the forest was first cooked using diesel in the factory area, in order to avoid fungi and insect attacks. Then, the rattan was dried, separated, and sorted according to size. The RFW from manufactured furniture, which came in the form of chips and powder, were used in this research. The RFW was sieved using a manual sieve to separate all unnecessary materials such as large chips, dust, rubbish, and sand.

\subsection{Chemical Treatment for Rattan Furniture Waste}

The alkaline treatment was applied to the RFW in the form of chips, and the parameters used for this treatment were taken from a previous study [11]. Sodium hydroxide $(\mathrm{NaOH})$ in pellet form was crushed using a white porcelain mortar until those pellets turned into fine particles. One gram of the $\mathrm{NaOH}$ powder was added to $100 \mathrm{ml}$ of distilled water, in order to produce a $1 \%$ of $\mathrm{NaOH}$ solution. The solution was stirred until the $\mathrm{NaOH}$ powder completely dissolved. The RFW chips were immersed completely in the $1 \%$ of $\mathrm{NaOH}$ solution for 10 minutes. Immediately after that, the chips were drained and washed using tap water. After that, the chips were stored in the oven at $35^{\circ} \mathrm{C}$ for two days.

\subsection{Characterization of Rattan Furniture Waste}

The RFW was characterised after being treated in alkaline treatment for comparison with untreated RFW. The characterisation done on untreated and treated RFW samples were for physical appearance, composition of material using a chemical test and Fourier transform infrared spectroscopy (FTIR) analysis, as well as a morphology test using SEM.

\subsubsection{Chemical Treatment for Rattan Furniture Waste}

The chemical component test was prepared to discover the contents of lignin, hemicelluloses, cellulose, and ash, according to the methods listed in Table 1.

Table 1: Chemical test of RFW

\begin{tabular}{ccc}
\hline Component & Method & Reference \\
\hline Lignin & Klason lignin method & 29 \\
Hemicellulose & Wise method & 30 \\
Cellulose & TAPPI 203 om-93 & 29 \\
Ash & TAPPI 211 om-02 & 29 \\
\hline
\end{tabular}

\subsubsection{Fourier Transform Infrared Spectroscopy}

A Perkin Elmer spectrum 2000 spectrometer was used for the FTIR analysis to determine the presence of a functional group at mode of 24 scans under resolution range of 550 to $4000 \mathrm{~cm}^{-1}$. The samples, in powder form, were inserted into the crystal spectrometer and the pressure arm was rotated clockwise until the "force gauge" reached 100.

\subsubsection{Morphology Test of Rattan Furniture Waste}

The morphological analysis was performed using scanning electron microscopy (SEM) model JSM-560 at operating voltage of $7 \mathrm{kV}$. The samples used were non-conductive material, thus these samples were coated with palladium $(\mathrm{Pd})$, and were put on the 
aluminium holder using double tape before being placed in the SEM machine. Observation of the samples' morphology was then conducted.

\subsection{Fabrication of Binderless Particleboard (BPB) Panels}

The untreated and treated RFW in chip form were blended to reduce them to the size of $50 \mu \mathrm{m}$ that were sieved using an electronic sieve machine with a parameter of $10 \mathrm{~mm}$ amplitude for 30 minutes. The sieved powders were dried in an oven for 3 days at $31{ }^{\circ} \mathrm{C}$ before being used to fabricate the BPB. After that, the dried powder was put in a mould of $110 \mathrm{~mm} \times 110 \mathrm{~mm}$ dimension, and subsequently pressed using a hot-press machine at a pressing temperature of $180{ }^{\circ} \mathrm{C}$ for 5 minutes. The fabricated BPB panels were labelled according to their types.

\subsection{Evaluation of Panel Properties}

These panels were prepared for property performance evaluation in terms of mechanical properties (three-point bending and internal bonding tests), dimensional stability properties (water absorption and thickness swelling tests), as well as their morphologies to validate the results from the tests. The panels were cut and labelled according to JIS A5908 [14] depending on their type of test

\subsubsection{Three Point Bending Test}

This test was performed to determine the strength of BPB panels through the modulus of rupture (MOR) in Eqn. 1. The measurement of panel width and thickness were taken before being placed in between two parallel supporting pins. The procedures were followed as described in the board standard, where the loading force of $10 \mathrm{~mm} / \mathrm{min}$ per load was applied to the middle of the sample as in Eqn. (1).

$$
M O R(M P a)=\frac{3 P L}{2 b t^{2}}
$$

where, $P=$ maximum load $(\mathrm{N}), L=$ length of $\operatorname{span}(\mathrm{mm}), b=$ panel width $(\mathrm{mm}), t=$ panel thickness (mm)

\subsubsection{Internal Bonding Test}

The panels were cut into a dimension of $50 \mathrm{~mm} \times 50 \mathrm{~mm}$, according to the board standard, where the width and thickness of the panels were measured. The device-testing metallic grip was covered with masking tape to prevent an over-gripped clamping onto the panel during testing. The vertical tension loading speed of $2 \mathrm{~mm} / \mathrm{min}$ was applied, and the internal bonding (IB) was calculated using Eqn. (2).

$$
I B(M P a)=\frac{P^{\prime}}{2 b L}
$$

where, $P^{`}=$ maximum load $(\mathrm{N})$ at the time of failing force, $b=$ panel width $(\mathrm{mm}), L=$ panel length $(\mathrm{mm})$

\subsubsection{Dimensional Stability Test}

The panels with a dimension of $50 \mathrm{~mm} \times 50 \mathrm{~mm}$ were used to perform water absorption (WA) tests according to board standard. Each sample was weighed $\left(\mathrm{w}_{1}\right)$ using an electronic balance and thereupon the panels were fully immersed in the water for 24 hours. After that, the panels were taken out and dried on tissue paper for 10 minutes to remove excess water. The panels were weighed again, w2, and the WA was calculated using Eqn. (3). 


$$
W A(\%)=\frac{w_{2}-w_{1}}{w_{1}} \times 100
$$

where, $w_{1}=$ weight before immersion $(\mathrm{g}), w_{2}=$ weight after immersion $(\mathrm{g})$

The same panels were used for the thickness swelling (TS) test. The thickness of each panel was measured at 4 different points at using a Vernier calliper, and the average thickness was taken as $t_{1}$. Then, the panels were immersed in water, in a transparent beaker container at room temperature for 10 minutes. After 10 minutes, the panels were taken out from the beaker and the average thickness $\left(t_{2}\right)$ was measured at the same locations as the previous measurement. The TS was calculated using Eqn. (4).

$$
\operatorname{TS}(\%)=\frac{t_{2}-t_{1}}{t} \times 100
$$

where, $t_{1}=$ thickness $(\mathrm{mm})$ before immersion in water, $t_{2}=$ thickness $(\mathrm{mm})$ after immersion in water

\subsubsection{Morphology Test}

The morphology test of the panels was carried out using a SEM machine to observe the internal structure of the BPB, using the same procedures applied as above.

\section{RESULTS AND DISCUSSION}

\subsection{Characterization of Rattan Furniture Waste}

For a natural fibre composite, alkaline treatment is one of the most effective techniques to modify the surface of the fibre. Previous studies [15-20] described the treatment, applied sodium hydroxide $(\mathrm{NaOH})$ at different concentrations, to have diverse effects on the fibre surface. High concentration of alkali caused deterioration to the fibres, which was proven by the occurrence of holes seen in SEM micrographs [19, 20]. Alkaline treatment eradicates impurities on the fibres such as hemicelluloses, lignin, and pectin, yet it surges the degree of crystallization of cellulose that results in a roughened surface on the fibres [11,21,22]. Figure 1(a) and 1(b) show the original colour of the RFW taken from the furniture factory and the RFW after alkaline treatment, respectively. The colour changed after the RFW underwent alkaline treatment, from light yellow to dark yellowish, which was proof of a chemical modification occurring during alkaline treatment. This change was in agreement with a previous study [11] that stated that degradation products from hemicelluloses caused darker tonality to the material used.
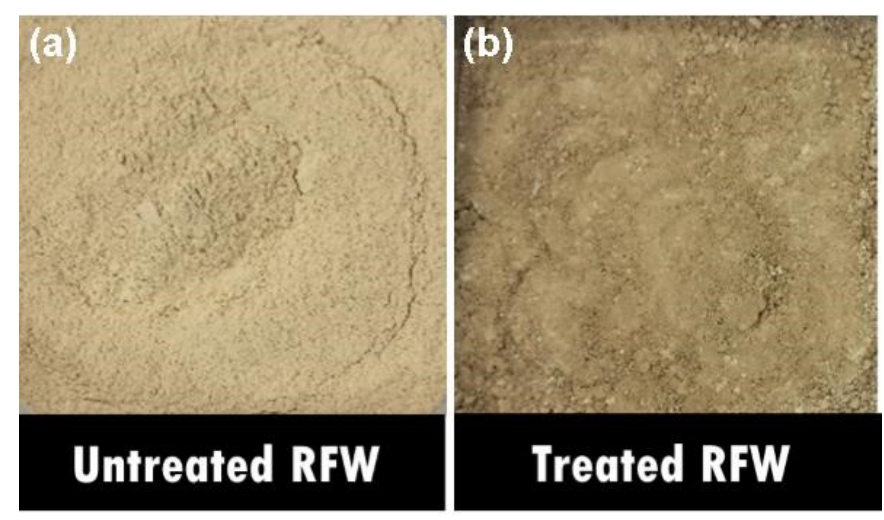

Fig. 1: Pictures of (a) untreated and (b) treated RFW fibres. 
Table 2: Chemical composition of untreated and treated RFW

\begin{tabular}{ccc}
\hline $\begin{array}{c}\text { Chemical } \\
\text { Composition }\end{array}$ & $\begin{array}{c}\text { Untreated RFW } \\
(\%)\end{array}$ & $\begin{array}{c}\text { Treated RFW } \\
(\%)\end{array}$ \\
\hline Lignin & 21.0 & 18.4 \\
Hemicellulose & 45.6 & 31.0 \\
Cellulose & 34.3 & 38.5 \\
Ash & 5.4 & 3.5 \\
\hline
\end{tabular}

Table 2 lists the chemical composition of the main components in the untreated and treated RFW. Lignin, hemicellulose, and ash content decreased after the alkaline treatment. The hygroscopicity properties of the fibres decreased significantly as the hemicellulose content was removed by almost $32 \%$ from the original content, thus affecting properties of the BPB panels and improving its dimensional stability [11,17]. Furthermore, mechanical interlocking of fibres improved by removing impurities through the alkaline treatment [22]. Although lignin plays an important role in producing BPB panels with good properties, the removal of lignin was replaced by other factors that contributed to binding the fibres together such as physical consolidation or mechanical interlocking after the treatment process $[22,23]$. This analysis also indicated that cellulose content increased by about $10.9 \%$ from the original cellulose content of the untreated RFW. This resulted in an increased degree of crystallization of fibres resulting in fabricated panels that have good strength $[23,24]$. All these factors significantly contributed to improving properties of the fabricated BPB panels in terms of their mechanical and physical characteristics.

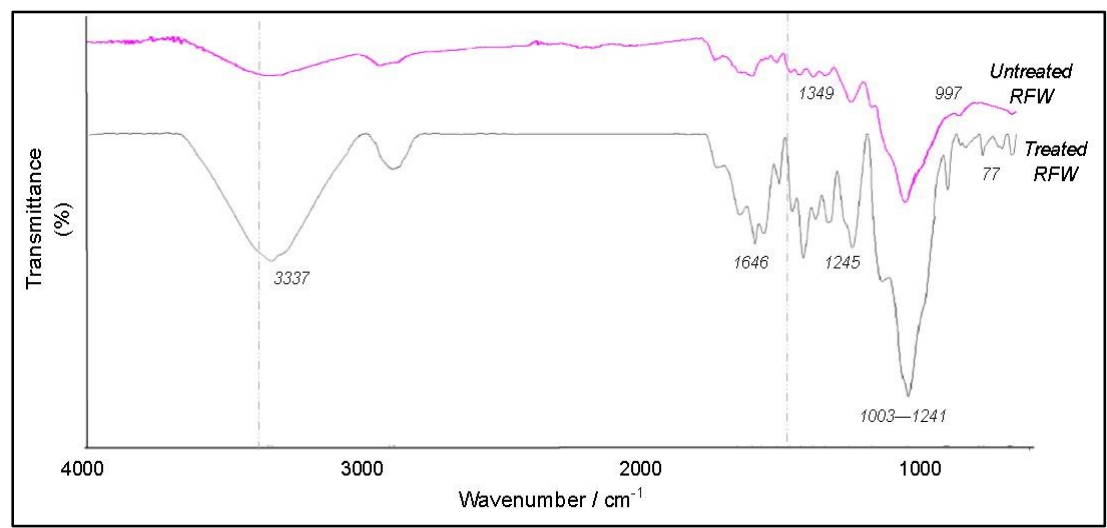

Fig. 2: Comparison of FTIR spectra of untreated and treated RFW.

Table 3: Comparison of FTIR spectra of untreated and treated RFW

\begin{tabular}{cc}
\hline Wave number $\left(\mathbf{c m}^{-\mathbf{1}}\right)$ & FTIR band position \\
\hline 3337 & O-H stretching, cellulose, hemicellulose, lignin, pectin \\
1646 & $\mathrm{C}=\mathrm{O}$ stretching, acetyl and carboxyl group of \\
hemicellulose & Alcohol group of cellulose OH deformation \\
1329 & Hemicellulose, pectin, epidermal waxy tissue \\
1245 & C-O-C symmetric, polysaccharides mainly cellulose \\
$1241-1003$ & C-O stretching, vibration of cellulose and hemicellulose \\
997 & Lignin components \\
771 &
\end{tabular}


The infrared spectra of the untreated and treated RFW samples were assessed by FTIR spectroscopy, as demonstrated in Fig. 2, whereas the obtained band positions are explained in Table 3. There were significant differences in infrared spectra for the RFW after alkaline treatment. The band at $3337 \mathrm{~cm}^{-1}$ was assigned to $\mathrm{O}-\mathrm{H}$ stretching vibration of cellulose, hemicellulose, lignin, and pectin structures $[11,17,20]$. Alkaline treatment weakened this band's intensity due to removal of those constituents. Meanwhile, the band at $1646 \mathrm{~cm}^{-1}$ decreased due to removal of $\mathrm{C}=\mathrm{O}$ stretching vibration of acetyl and carbonyl groups of hemicellulose $[17,20,24]$. The finding of decreased intensity at $1329 \mathrm{~cm}^{-1}$ is consistent with alkaline treatment carried out by Ramadevi and his team [17]. It is associated with an alcohol group of cellulose $\mathrm{OH}$ deformation. The band position of $1245 \mathrm{~cm}^{-1}$ shows a peak decline, indicating the removal of hemicellulose, pectin, and epidermal waxy tissue $[11,17]$. The C-O-C symmetry arises at the band position of $1241 \mathrm{~cm}^{-1}$, containing polysaccharides, mainly cellulose [23]. The vanishing band position at $997 \mathrm{~cm}^{-}$is explained by the removal of cellulose and hemicellulose due to $\mathrm{C}-\mathrm{O}$ stretching vibration subjected to the alkaline treatment [11]. At band $771 \mathrm{~cm}^{-1}$, the $\mathrm{CH}$ bond is out of plane demonstrating the elimination of lignin during the alkaline treatment.
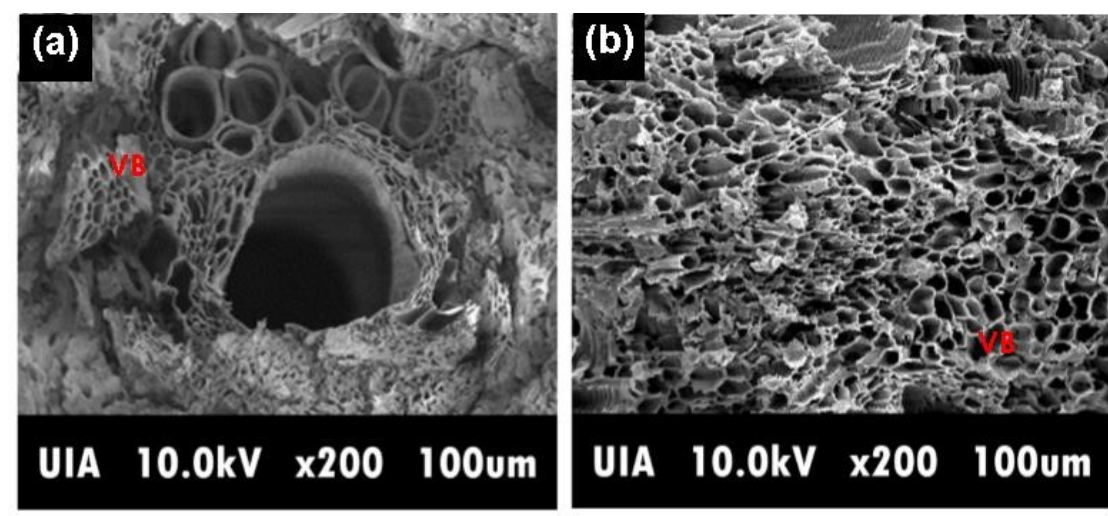

Fig. 3: Pictures of untreated (left) and treated (right) RFW at 200x magnification.

Figure 3 displays the micrograph of the untreated and treated RFW for SEM analysis under 200X magnification. The untreated RFW in Fig. 3(a) shows vascular bundles (VB) and parenchyma cells that were covered with the fibres' main constituents, consisting of hemicelluloses, cellulose, lignin, pectin, and other impurities. There was a wide metaxylem vessel along with numerous protoxylem vessel elements amongst the vascular bundles [25]. In Fig. 3(b), the treated RFW exhibited cleaner fibres and increased cell walls indicating that alkaline treatment had washed away impurities and removed cell wall components that were stuck in vascular bundles [17, 23-26]. These made the vascular bundles become more visible and the fibre surface rougher. The treatment process required the RFW to be immersed in the solution where the fibres absorbed some solution and thus had a higher swelling level that increased the particle sizes with more flexible fibres [11]. The rough surfaces helped mechanical interlocking due to the release of the hydroxyl groups on the fibre surface, thus increasing the fibre-fibre bonding [22]. The treatment also changed the cellulose structure that increased the degree of crystallization with tighter chain packaging so the RFW drastically absorbed less moisture [23, 24]. This resulted in improved mechanical properties with better dimensional stability for the fabricated BPB. 


\subsection{Properties Evaluation of BPB Panels}

The fabricated BPB panels were evaluated based on their properties of strength, internal bond, dimensional stabilities, as well as their morphologies. There was an obvious colour change for the treated BPB panel made from treated RFW, which had a darker colour compared to the untreated BPB panel.

\subsubsection{Effects of Alkaline Treatment on Mechanical Properties of Panels}

The strength of the BPB panels is identified using static bending to reflect the BPB behaviour by determining the modulus of rupture (MOR) of the panels [23]. Figure 4 displays the graph of the untreated and treated BPB panels with MOR values of $28.5 \mathrm{MPa}$ and 44.4 MPa, respectively. Both BPB panels meet the minimum requirement of the board standard, which is $18.0 \mathrm{MPa}$ [14]. In previous work [2, 3, 7, 11], they found out that bonding mechanisms of boards are attributable to chemical bonding and physical consolidation amongst fibres, along with thermoplastic flow of natural binders inside fibres. As sufficient heat was applied to the fibre during the hot-pressing process, the lignin inside the fibres melted and flowed to the surface of the fibres. Lignin acts as a natural binder, distributed amongst fibres hence producing a BPB of good strength [4]. It is important to note that adequate heat applied with sufficient pressing pressure and optimum pressing time are required as vital parameters in fabricating $\mathrm{BPB}[3,7]$. The MOR value of the treated BPB panel increases $35.8 \%$ compared to the MOR value of untreated BPB, which is in agreement with previous studies $[11,19]$. The main components of RFW are cellulose, hemicellulose, and lignin [25]. Alkaline treatment removes these constituents from the fibres and cause rougher fibre surfaces $[11,26]$. Furthermore, this treatment reduces the diameter of the fibres resulting in increased aspect ratios [24, 27]. Apparently, these two factors of rougher fibre surface and bigger aspect ratios enhance mechanical interlocking and bonding reaction between the fibres. The amount of crystalline cellulose on the fibres also increased [23], leading to improvement in mechanical properties due to interruption of hydrogen bonding on the fibre surfaces.

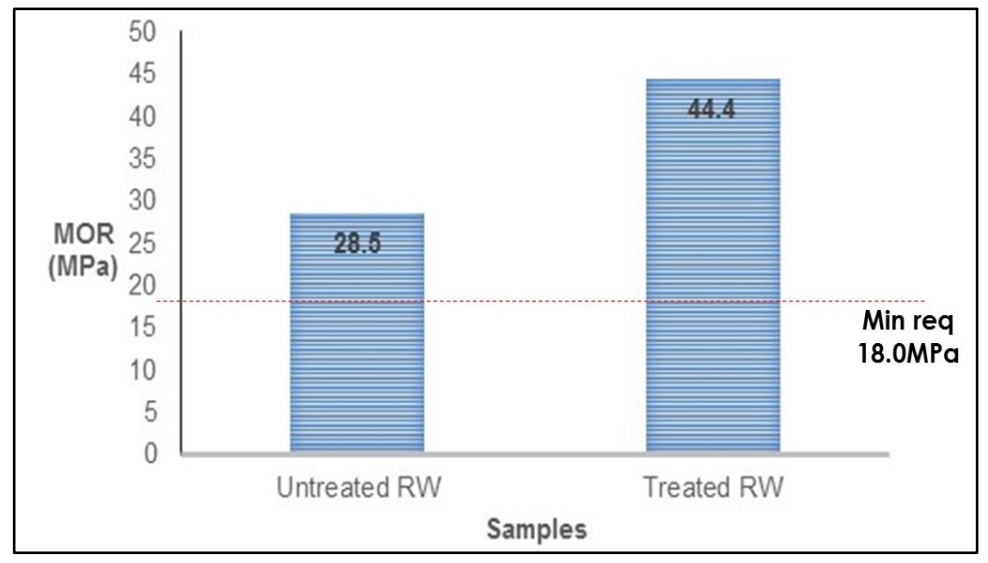

Fig. 4: Graph of Modulus of Rupture (MOR) for untreated and treated BPB panels.

Figure 5 shows the graph of internal bonding (IB) of the untreated and treated BPB panels, where the IB of the untreated and treated $\mathrm{BPB}$ is $0.26 \mathrm{MPa}$ and $0.44 \mathrm{MPa}$, respectively. The IB test was conducted to determine the internal bond of fibres in the fabricated BPB panels. The minimum requirement of IB value according to JIS A5908 [14] is $0.30 \mathrm{MPa}$, where only the treated $\mathrm{BPB}$ panel met the requirement. The IB value of the treated BPB panel improved by about $40.9 \%$ compared to the untreated BPB panel that also 
contributed to tremendous mechanical properties in the BPB panels. RFW is categorised as a natural fibre that has high hygroscopic properties due to the presence of the hydroxyl group and other polar groups in fibre components [23, 24, 28]. Therefore, this resulted in poor wettability and weak interfacial bonding between the fibres. On the other hand, the hydrogen bonding on the fibres' surfaces were disrupted through the alkaline treatment, where it also increased the cellulose crystallinity of the fibres that contributed to increasing the surface roughness of BPB panels [22, 24, 28]. Results additionally suggested that this disruption condition facilitates mechanical interlocking between fibres.

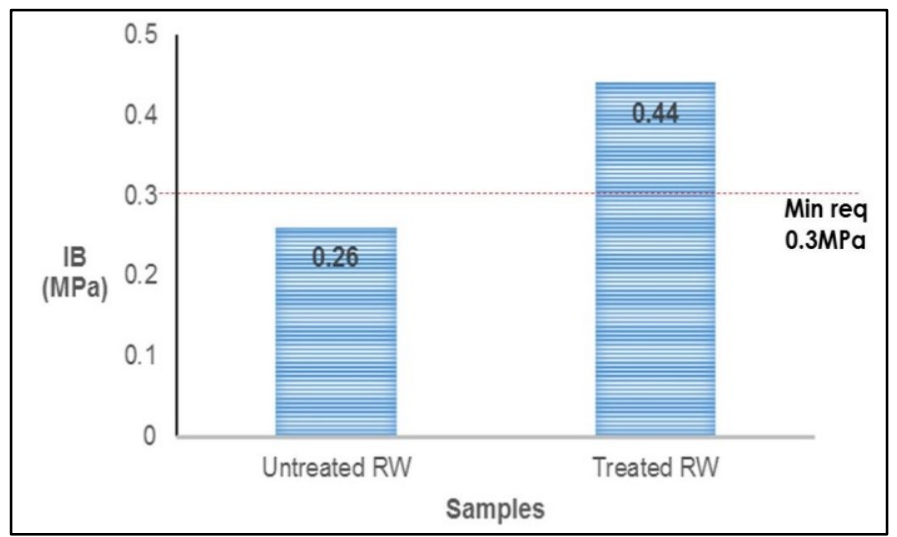

Fig. 5: Graph of Internal Bonding (IB) for untreated and treated RFW BPB.

\subsubsection{Effects of Alkaline Treatment on Dimensional Stabilities of Panels}

The dimensional stabilities in terms of water absorption (WA) and thickness swelling (TS) of BPB panels are illustrated in Fig. 6. The percentage of WA for the untreated and treated BPB panels are 54.5\% and $42.9 \%$, while the percentage of TS for the untreated and treated BPB panels are 19.6\% and 6.8\%, respectively. The standard JIS A5908 set the normal Type- 18 particleboard at no more than $12 \% \mathrm{TS}$, which means the treated BPB panel achieved the standard requirement [14]. One of the components that is responsible for the hygroscopic properties of the RFW and natural fibres is hemicellulose. Fibre hemicellulose have been removed by chemical modification throughout the alkaline treatment $[11,17,25]$, thus decreasing the percentage of WA and TS of the BPB panels. In addition to that, the treatment destroyed the hydroxyl group on the fibre surfaces such that the fibres had less affinity to water [24]. As previously reported by Esteve and Pereira [23], the chemical modification leads to high cellulose cross-linking where molecules become less elastic, so micro-fibrils have less possibility to expand and absorb water. Therefore, the alkaline treatment has improved dimensional stabilities of the treated BPB panels, a fact that was verified in the great strength and excellent IB properties of the BPB panels. The mechanism of the alkaline treatment is demonstrated in Fig. 7, where the hydrophilic properties of the fibres were turned into hydrophobic properties as the water molecules were released from the fibres during the treatment process [17, 24, 25, 27]. 


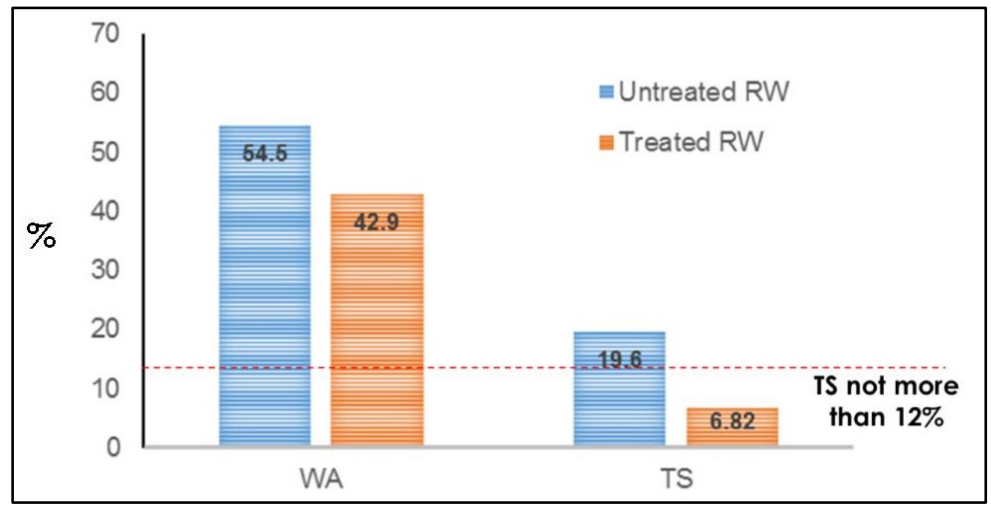

Fig. 6: Graph of dimensional stability of untreated and treated BPB samples.

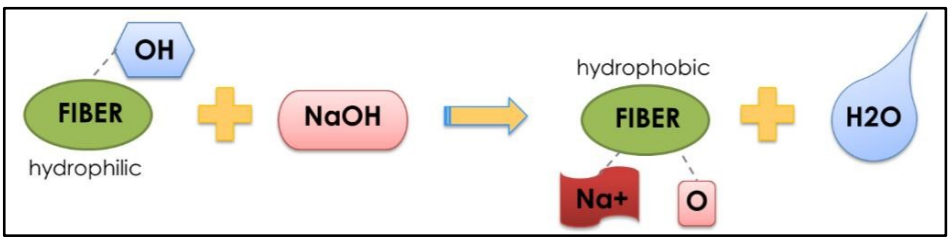

Fig. 7: Mechanism of alkaline treatment process.

\subsubsection{Effects of Alkaline Treatment on Morphology of Panels}

The SEM analysis was conducted to observe the surface morphology of the fabricated BPB panels made from the untreated and treated RFW, as illustrated in Fig. 8. It clearly showed that the fibres were completely compressed when heat and pressure were applied in the hot-pressing process $[3,4,7]$. The untreated BPB panel in Fig. 8(a) had a smooth surface attributable to the good fluidity of lignin to fibre surface when the heat was applied to the fibres. Lignin acts as a natural binder in the fabrication process of BPB panels [4]. However, the treated BPB panel in Fig. 8(b) had rough surface that was obvious to the naked eye, as alkaline treatment removed various constituents inside the fibres [20-26]. Fibres attached closely to each other without impurities at the fibre surfaces, increasing interlocking strength between the RFW fibres. This observed figure is evidence of removal of chemical components inside the fibre after the alkaline treatment process, as explained in the previous sub-section.
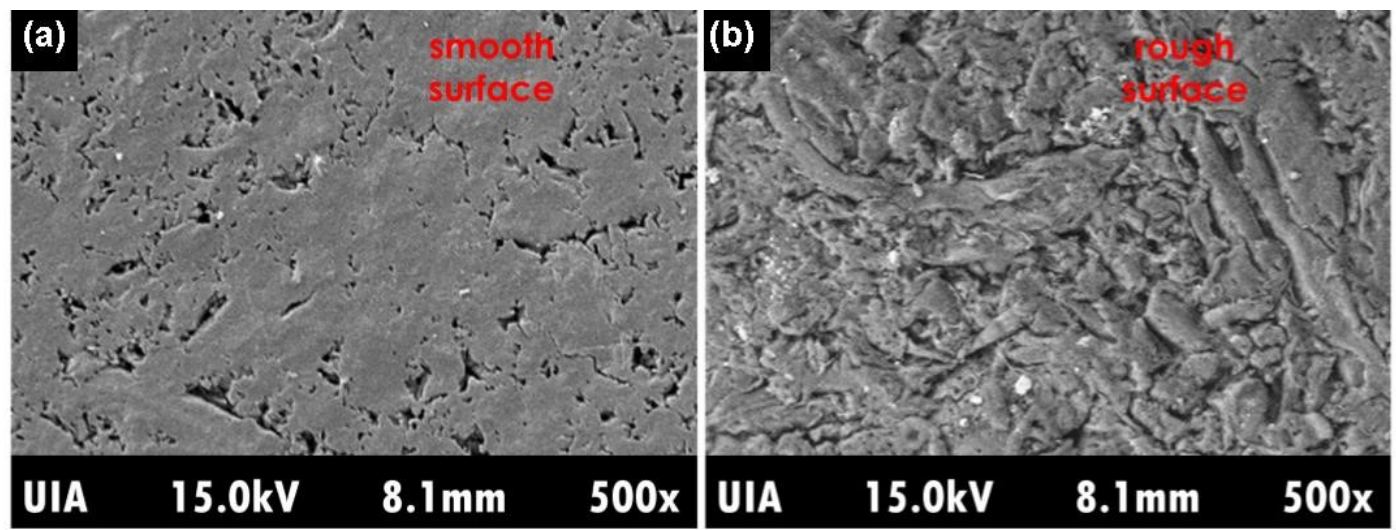

Fig. 8: SEM micrographs of untreated and treated BPB. 


\section{CONCLUSION}

- The alkaline treatment removed impurities consisting of hemicellulose, lignin, ash, and pectin, which was proven through observed change in colour, chemical tests, and FTIR analysis.

- SEM micrographs of the RFW illustrated cleaner and rougher fibres after the alkaline treatment, which helped in improving the mechanical interlocking between the fibres.

- The treated BPB panels met the requirements of the board standard especially in terms of thickness swelling.

- Removal of hemicellulose was responsible for the reduction of hygroscopic properties of the fibres.

- The hydrogen molecules were disrupted and released during the alkaline treatment which reduced the moisture absorption by the fibres.

\section{ACKNOWLEDGEMENTS}

The authors wish to thank the Ministry of Higher Education, Malaysia for financial support of sponsorship scheme of Grant No. FRGS15-206-0447, and the lecturers and technicians at the International Islamic University Malaysia (IIUM) for the help and facilities provided.

\section{REFERENCES}

[1] Ganiron TUJ. (2013) An investigation of moisture performance of sawdust and banana peels ply board as non-veneer panel. International J. of u- and e- Service, Science and Technology, 6(3):43-54.

[2] Hashim R, Wan Nadhari WS, Sato MO, Hiziroglu S, Kawamura F, Sugimoto T, Seng TG, Tanaka R. (2012) Properties of binderless particleboard panels manufactured from oil palm biomass. BioResources, 7(1):1352-1365.

[3] Quintana G, Velasquez J, Betancourt S, Ganan P. (2009) Binderless fiberboard from steam exploded banana bunch. Industrial Crops and Products, 29(1):60-66.

[4] Okuda N, Sato M. (2004) Manufacture and mechanical properties of binderless boards from kenaf core. J. of Wood Science, 50(1):53-61.

[5] Xu J, Widyorini R, Yamauchi H. (2006) Development of binderless fibreboard from kenaf core. J. of Wood Science, 52(3):236-243.

[6] Panyakaew S, Fotios S. (2011) New thermal insulation boards made from coconut husk and bagasse. Energy and Buildings, 43(7):1732-1739.

[7] Zhou RX, Zheng F, Li H, Lu C. (2010) An environment-friendly thermal insulation material from cotton stalk fibers. Energy and Buildings, 42(7):1070-1074.

[8] Luo P, Yang C. (2012) Production of binderless particleboard using rice straw pre-treated with liquid hot water. Applied Mechanics and Materials, 200:331-334.

[9] Olorunnisola AO, Adefisan OO. (2001) Trial production and testing of cement-bonded particleboard from rattan furniture waste. Wood and Fiber Science, 34(1):116-124.

[10] Olorunnisola AO. (2004) Briquetting of rattan furniture waste. J. of Bamboo and Rattan, 3(2):139-149.

[11] Geng X, Zhang SY, Deng J. (2006) Alkaline treatment of black spruce bark for the manufacture of binderless fiberboard. J. of Wood Chemistry and Technology, 26:313-324.

[12] Das S, Saha AK, Choudhury PK, Basak RK, Mitra BC, Todd T, Lang S, Rowell RM. (2001) Effect of steam pre-treatment of jute fibre on dimensional stability of jute composite. J. of Applied Polymer Science, 76(11):1652-1661.

[13] Corradini E, Morais L, Rosa M, Mazzetto S, Mattoso L, Agnelli J. (2006) A preliminary study for the use of natural fibres as reinforcement in starch-glutten-glycerol matrix. Macromolecular Symposia, 245-246: 558-564. 
[14] JIS - A5908 Particleboards (2003) Japanese Standards Association, Tokyo, Japan, pp 1-24.

[15] Silverstein RA, Chen Y, Sharma-Shivappa RR, Boyette MD, Osborne J. (2007) A comparison of chemical pretreatment methods for improving saccharification of cotton stalks. Bioresource Technology, 98(16):3000-3011.

[16] Rokbi M, Osmani H, Imad A, Benseddiq N. (2011) Effect of chemical treatment on flexure properties of natural fiber-reinforced polyester composite. Procedia Engineering, 10:20922097.

[17] Ramadevi P, Sampathkumar D, Srinivasa CV, Bennehalli B. (2012) Effect of alkali treatment on water absorption of single cellulosic abaca fiber. BioResources, 7(3):35153524.

[18] Pelaez-Samaniegoa MR, Yadamac V, Garcia-Pereza M, Lowelle E. (2015) Abundance and characteristics of lignin liquid intermediates in wood (Pinus ponderosa Dougl. ex Laws.) during hot water extraction. Biomass and Bioenergy, 81:117-128.

[19] Machaka M, Basha H, Chakra DHA, Elkordi A. (2014) Alkali treatment of fan palm natural fibers for use in fiber reinforced concrete. European Scientific J., 10(12):186-195.

[20] Xia Z, Li XXJ. (2010) Effect of alkaline treatment of straw fiber on mechanical properties of cement-bonded straw fiber board. In Mechanic Automation and Control Engineering (MACE), International Conference IEEE: 26-28 June 2010; Wuhan, China; pp. 3006-3008.

[21] Gonzalez-Murillo C, Ansell MP. (2009) Mechanical properties of henequen fibre/epoxy resin composites. Mechanics of Composite Materials, 45:435-442.

[22] Yan L, Chouw N, Yuan X. (2012) Improving the mechanical properties of natural fiber fabric reinforced epoxy composites by alkali treatment. J. of Reinforced Plastic and Composites, 31(6):425-437.

[23] Esteves BM, Pereira HM. (2009) Wood modification by heat treatment: A review. BioResources, 4(1):370-404.

[24] Cyras VP, Vallo C, Kenny JM, Vazquez A. (2004) Effect of chemical treatment on the mechanical properties of starch-based blends reinforced with sisal fibre. J. of Composite Materials, 38(16):1387-1399.

[25] Ebanyenle E, Oteng-Amoako AA. (2003) Anatomy and identification of five indegeneous rattan species of Ghana. Ghana J. Forestry, 11(2):77-90.

[26] Srinivasa CS, Suresh YJ, Prema KWP. (2012) Mechanical behaviour of areca fiber reinforced epoxy composites. Advanced Polymer Technology, 31(4):319-330.

[27] Channalli M, Siddeswarappa DB. (2015) Effect of alkali treatments on natural filler content performance of polymer composites. International J. of Engineering Research \& Technology (IJERT), 4(10):11-16.

[28] Kabir MM, Wang H, Aravinthan T, Cardona F, Lau KT. (2011) Effects of natural fiber surface on composite properties: A review. In $1^{\text {st }}$ International Postgraduate Conference on Energy, Designing and Developing the Built Environment for Sustainable Wellbeing (eddBE2011) Proceedings: 27-29 April 2011; Brisbane, Australia; pp. 94-99.

[29] TAPPI Standards and Suggested Methods. TAPPI Press, Atlanta, GA, USA.

[30] Wise LE, Murphy M, D'Addieco AA. (1946) Chlorite holocellulose, its fractionation and bearing on summative wood analysis and on studies on the hemicellulose. Paper Trade J., 122(2):35-43. 